\title{
PERTUMBUHAN EKONOMI, UPAH MINIMUM DAN TINGKAT PENGANGGURAN DI KALIMANTAN BARAT
}

\author{
Mochamad Rofik ${ }^{1}$, Novi Puji Lestari ${ }^{2}$, Rizkia Septianda ${ }^{3}$ \\ Pusat Pengembangan Ekonomi, Bisnis dan Kewirausahaan, Universitas Muhammadiyah Malang ${ }^{1}$ \\ Fakultas Ekonomi dan Bisnis, Universitas Muhammadiyah Malang ${ }^{2}$ \\ Program Studi Ekonomi Pembangunan, Universitas Muhammadiyah Malang ${ }^{3}$
}

\begin{abstract}
Abstrak
Tujuan artikel ini adalah untuk menganalisis karakteristik dan pengaruh pertumbuhan ekonomi dan kenaikan upah minimum terhadap pengangguran di Kalimantan Barat. Penelitian ini merupakan penelitian deskriptif dengan pendekatan kualitatif-kuantitatif, yakni menggunakan metode analisis statistik deskriptif dan menggunakan analisis regresi data panel. Selama kurun waktu 2011-2015 pengangguran di Kalimantan Barat menunjukkan tren kenaikan, hal ini bersamaan dengan tren pertumbuhan ekonomi yang terus mengalami perlambatan dan kecenderungan upah minimum yang terus mengalami kenaikan. Mayoritas sektor ekonomi yang masih betumpu pada sektor pertanian dan pertambangan adalah salah satu penyebab minimnya lapangan pekerjaan, selain itu, laju inflasi tahunan yang cukup tinggi juga menyebabkan upah minimum di Kalimantan Barat selalu mengalami kenaikan yang cukup signifikan.
\end{abstract}

Kata Kunci: Pertumbuhan ekonomi. upah minimum, pengangguran, Kalimantan Barat

\section{PENDAHULUAN}

Pengangguran adalah angkatan kerja yang sedang mencari atau belum mendapatkan pekerjaan (Rodrik, 2008; Statistics SA, 2014). Pengangguran umumnya disebabkan karena proporsi jumlah angkatan kerja yang tidak sebanding dengan proporsi jumlah lapangan kerja. Angkatan kerja yang tidak terserap lapangan kerja inilah yang umumnya menjadi penyebab utama pengangguran (Kingdon \& Knight, 2007). Tingginya tingkat pengangguran di suatu negara atau wilayah akan membawa dampak negatif terhadap perekonomian. Pengangguran akan menjadi beban tidak hanya bagi pemerintah, namun juga berdampak terhadap tatanan sosial hingga lingkungan. Tingginya tingkat pengangguran di suatu kawasan, akan memicu peningkatan masalah-masalah sosial seperti kriminilatias, memperlebar jarak ketimpangan, kemiskinan hingga pencemaran lingkungan yang disebabkan oleh pemukiman kumuh (Dieckhoff, 2011; Wiemers, 2014).

Proporsi lapangan pekerjaan yang tidak sebanding dengan angkatan kerja salah satunya disebabkan terhambatnya investasi. Berbagai kondisi seperti keadaan kawasan yang kurang kondusif mulai dari aspek politik, keamanan hingga keadaan lingkungan adalah faktor utama terhambatnya investasi di sebuah wilayah. Berikutnya, faktor birokrasi yang kurang efisien serta infrastruktur yang belum mumpuni juga menjadi salah satu sebab utama lambatnya penanaman modal modal domestik mapun oleh investor asing. Terhambatnya investasi akan menyebabkan pertumbuhan ekonomi mengalami perlambatan hingga stagnasi, roda perekonomian yang cenderung melambat atau bahkan stagnan merupakan indikasi perekonomian sebuah wilayah mengalami depresi, dampak dari depresi bagi sebuha salah satunya adalah menurunnya kesempatan kerja bahkan jika depresi terjadi dengan ekstrim bukan hanya menurunnya kesempatan kerja tapi juga hilangnya pekerjaan (Alvarado, Iñiguez, \& Ponce, 2017; Azman-Saini, Baharumshah, \& Law, 2010; Iamsiraroj, 2016).

Beberapa studi empirik mempelihatkan jika pertumbuhan ekonomi mampu menciptakan lapangan pekerjaan baru dengan persentase yang berbeda-beda di setiap negara. Studi terhadap negara-negara di Eropa Timur menunjukkan bahwa pertumbuhan ekonomi sebesar 1\% mampu menurunkan pengangguran sebesar 0,08\% (Özgür Bayram Soylu, İsmail Çakmak, 2017). Sementara itu studi untuk negara-negara arab menunjukkan bahwa peningkatan $1 \%$ pertumbuhan ekonomi mampu menurunkan pengangguran sebesar $0,16 \%$. Namun, studi lain juga mengungkapakan bahwa peran pertumbuhan ekonomi dalam mengurangi pengangguran sangat bergantung terhadap struktur pertumbuhan ekonomi sebuah negara. Misal, Aljazair, walau pertumbuhannya cukup tinggi akan tetapi tidak berdampak signifikan terhadap pennguranagan pengangguran hal ini disebabkan pertumbuhan ekonomi utamanya ditopang sektor ekstraktif.

\footnotetext{
1 Mochamadrofik81@gmail.com
} 
(Al-Habees \& Rumman, 2012). Faktor lain yang berpengaruh terhadap tingkat penganguuran di sebuah kawasan adalah upah minimum. Upah minimum memang menjadi salah satu isu sensitif baik bagi akademisi dan pengambil kebijakan. Para pendukung kenaikan upah minimum meyakini bahwa kenaikan upah minimum bertujuan untuk mengurangi ketimpangan pendapatan khusunya pada golongan dengan pendapatan rendah (Cahuc \& Michel, 1996; Christiano, Eichenbaum, \& Trabandt, 2013; Mortensen \& Pissarides, 1994). Namun, di satu sisi banyak pihak yang percaya bahwa upah akan menyesuaikan dengan mekanisme pasar sehingga tidak perlu ada kebijakan upah minimum. Menurut mereka, upah minimum hanya akan membuat kekakuan pasar dan tidak menciptakan iklim usaha yang kondusif.

Upah yang terlalu tinggi akan membuat iklim usaha kurang baik, tingginya upah akan membuat beban perusahaan semakin besar sehingga tidak mampu bersaing dan pada akhirnya untuk bertahan perusahaan akan memilih untuk mengurangi jumlah pekerja melalui pemutusan hak kerja atau memindahkan pabrik keluar daerah dengan upah yang lebih rendah. Namun di sisi lain upah juga harus sesuai dengan standar biaya hidup minimum karena bagaimanapun hak-hak pekerja tidak bisa diabaikan. Disebabkan hal tersebut maka kebijakan mengenai upah minimum yang ditetapkan otoritas harus benarbenar mengakomodasi pengusaha da buruh. Di satu sisi harus tidak membebankan pengusaha dan di lain harus menjamin kelayakan hidup pekerja. Beberapa studi memperlihatkan jika peningkatan upah minimum berpengaruh positif terhadap meningkatnya pengangguran, misalnya studi di negara OECD menunjukkan bahwa peningkatan upah minimum sebesar $10 \%$ akan mengurangi tenaga kerja sebesar $0,7 \%$ dan meningkatkan pengangguran sebesar 0,64\% (Chong-Uk Kim, 2018).

Kalimantan Barat adalah salah satu provinsi yang berada di Pulau Kalimantan dengan ibu kota Provinsi Kota Pontianak. Luas wilayah Kalimantan Barat sekitar 7,53\% dari total luas Indonesia atau setara $146.807 \mathrm{~km}^{2}$. Kalimantan Barat merupakan Provinsi dengan kepadatan penduduk yang rendah, mayoritas kawasan Kalimantan Barat masih berupah hutan dan lahan pertanian dan perkebunan. Menurut BPS, (2018) Kalimantan Barat adalah Provinsi yang memiliki Tingkat Pengangguran Terbuka tertinggi kedua di Pulau Kalimantan. Oleh sebab itu, analisis mengenai karkateristik pengangguran di Kalimantan Barat perlu dilakukan sebagai landasan dalam mengembil kebijakan. Meninjau latar belakang yang telah dikemukakan, maka penelitian ini fokus untuk menganalisis sebaran pertumbuhan ekonomi dan pengangguran di Kalimantan Barat dan dampak pertumbuhan ekonomi dan kenaikan upah minimum terhadap jumlah pengangguran.

\section{TINJAUAN PUSATAKA}

\section{METODOLOGI PENELITIAN}

Data yang digunakan pada penelitian ini adalah pertumbuhan ekonomi, upah minimum, dan tingkat pengangguran terbuka Kabupaten/Kota di Provinsi Kalimantan Barat tahun 2011-2015. Penelitian ini menggunakan metode campuran, yaitu menggabungkan analisis secara deskriptif terhadap data-data statistik dan menggunakan metode regresi data panel untuk melakukan interprestasi secara inferensial. Model regresi data panel yang digunakan adalah sbb:

$\mathrm{Y}=\beta_{0} \mathrm{X}_{1}+\beta_{2} \mathrm{X}_{2}+\mathrm{e}$.

Keternagan:

$\begin{array}{ll}\mathrm{Y} & : \text { Tingkat Pengangguran Terbuka } \\ \beta_{1}, \beta_{2} & : \text { Koefisien Regresi Parsial } \\ X_{1} & : \text { Pertumbuhan Ekonomi } \\ X_{2} & : \text { Upah Minimum } \\ \mathrm{e} & : \text { Konstanta/ Intercept }\end{array}$

\section{HASIL DAN PEMBAHASAN}

Tingkat pengangguran terbuka di Kalimantan Barat selama tahun 2011 hingga 2015 menunjukkan kecenderungan tren yang terus meningkat. Tahun 2011 tingkat pengangguran di Kalimantan Barat ada diangka 3,53\% dan pada tahun 2015 naik menjadi 5,07\%. Rata-rata tingkat pengagguran di Kaliman Barat selama kurun waktu 2011-2015 adalah 3,92\%. Pada kurun waktu tesebut Kabupaten Pontianak mencatat rata-rata pengangguran tertinggi yakni sebesar $6,66 \%$ sedangkan rata-rata tingkat pengagguran terendah dicatat oleh kabupaten Sekadau, yakni sebesar 1,32\%. Lima Kabupaten/Kota mencatat rata-rata pennggaguran diatas rata-rata Propinsi, bahkan Kota Pontianak, Kabupaten Kubu Raya dan Kabupaten Singkawang rata-rata penganggurannya di atas $6 \%$.

Tabel 1. Tingkat Pengangguran Terbuka Kabupaten/Kota Kalimantan Barat (\%) 
Jurnal Inovasi Ekonomi Vol. 03 No.02 September 2018

\begin{tabular}{llllll}
\hline Kabupaten/Kota & 2011 & 2012 & 2013 & 2014 & 2015 \\
\hline Kab. Sambas & 2,99 & 3,11 & 3,03 & 3,7 & 4,48 \\
\hline Kab. Bengkayang & 3,32 & 3,3 & 2,3 & 3,74 & 3,15 \\
\hline Kab. Landak & 3,18 & 4,8 & 3,24 & 3,43 & 5,18 \\
\hline Kab. Mempawah & 3,35 & 4,67 & 5,66 & 5,57 & 7,12 \\
\hline Kab. Sanggau & 3,27 & 1,39 & 0,78 & 3,25 & 5,13 \\
\hline Kab. Ketapang & 3,7 & 1,95 & 4,7 & 2,06 & 4,29 \\
\hline Kab. Sintang & 3,38 & 2,05 & 2,24 & 3,06 & 2,48 \\
\hline Kab. Kapuas Hulu & 2,5 & 1,58 & 2,09 & 2,02 & 3 \\
\hline Kab. Sekadau & 2,93 & 0,6 & 1,44 & 0,31 & 2,97 \\
\hline Kab. Melawi & 3,08 & 2,9 & 3,99 & 2,46 & 3,03 \\
\hline Kab. Kayong Utara & 2,56 & 6,96 & 4,66 & 4,08 & 3,76 \\
\hline Kab. Kubu Raya & 4,52 & 6,06 & 9,26 & 6,18 & 6,11 \\
\hline Kota Pontianak & 5,35 & 5,35 & 6,12 & 7,05 & 9,44 \\
\hline Kota Singkawang & 5,34 & 5,75 & 4,59 & 8,22 & 6,12 \\
\hline
\end{tabular}

Sumber : Badan Pusat Statistik Kalimantan Barat

Selama kurun waktu 2011-2015 Kota Singkawang mencatatkan rata-rata pertumbuhan ekonomi tertinggi di Kalimantan Barat dengan rata-rata 6,49\%. Kota Singkawang mencarat tren positif dari tahun 2011 ke 2012 dan mulai mengalami tren penurunan sejak tahun 2013. Sementara itu Kabupaten Sanggau mencatat petumbuhuan terendah dengan rata-rata pertumbuhan 4,6\%. Tidak berbeda dengan Kota Singkawang, Kabupaten Sanggau juga mulai menunjukkan tren penurunan pertumbuhan ekonomi sejak tahun 2013 bahkan pada tahun 2015 mencatat pertumbuhan terendahnya selam 2011-2015 dengan pertumbuhan ekonomi hanya 3,15 padahal pada tahun 2011 pertumbuhan ekonomi Kabupaten Sanggau masih berada di angka 4,61. Selama 2011-2015 pertumbuhan ekonomi di Kalimantan Barat walau pertumbuhan ekonominya cukup fluktuaktif tren pertumbuhan cenderung mengalami penurunan. Bahkan pertumbuhan ekonomi di tahun 2015 berada di bahwah 5\%.

Tabel 2. Pertumbuhan Ekonomi Kabupaten/Kota Provinsi Kalimantan Barat (\%)

\begin{tabular}{llllll}
\hline Kabupaten/Kota & 2011 & 2012 & 2013 & 2014 & 2015 \\
\hline Kab. Sambas & 5,8 & 5,9 & 6,17 & 5,54 & 4,78 \\
\hline Kab. Bengkayang & 5,65 & 5,87 & 5,9 & 4,02 & 3,96 \\
\hline Kab. Landak & 6,9 & 5,42 & 5,2 & 4,93 & 5,11 \\
\hline Kab. Mempawah & 4,86 & 4,06 & 5,44 & 6 & 5,6 \\
\hline Kab. Sanggau & 4,61 & 6,03 & 5,98 & 3,26 & 3,15 \\
\hline Kab. Ketapang & 7,98 & 4,65 & 4,72 & 2,76 & 5,53 \\
\hline Kab. Sintang & 5,45 & 5,6 & 6,47 & 5,36 & 4,65 \\
\hline Kab. Kapuas Hulu & 4,56 & 4,75 & 5,23 & 3,98 & 4,67 \\
\hline Kab. Sekadau & 5,73 & 6,21 & 6,52 & 6,09 & 5,75 \\
\hline Kab. Melawi & 6,54 & 6,22 & 4,85 & 4,73 & 4,61 \\
\hline Kab. Kayong Utara & 5,93 & 5,78 & 5,25 & 5,65 & 5,03 \\
\hline Kab. Kubu Raya & 6,51 & 6,61 & 6,49 & 6,37 & 6,21 \\
\hline Kota Pontianak & 5,88 & 7,77 & 7,83 & 5,94 & 4,84 \\
\hline Kota Singkawang & 6,46 & 6,64 & 6,6 & 6,61 & 6,18
\end{tabular}

Sumber : Badan Pusat Statistik Kalimantan Barat 
Sementara itu, Kabupaten Ketapang selama 2011-2015 merupakan daerah di Kalimantan Barat dengan rata-rata kenaikan upah minimum mencapai 20\%. Sementara itu, Kabupaten Kapuas Hulu mencatat rata-rata kenaikan terendah selama lima tahun terakhir yakni sebesar $13,31 \%$. Secara umum propinsi Kalimantan Barat selama 2011-2015 mencatat kenaikan rata-rata kenaikan upah minimum sebesar $16 \%$. Tahun 2013 dan 2014 merupakan rata-rata kenaikan tertinggi dengan rata-rata kenaikan upah minimum sebesar 25\% dan 22\%. Kabupaten Ketapang pada 2015 merupakan Kabupaten dengan upah minimu tertinggi yakni sebesar Rp.1.800.000 dan daerah dengan upah minimum terkecil dicatat oleh Kab. Bengkayang dengan upah minimum sebesar Rp. 1.560.000.

Tahun 2013 saat Kalimantan Barat mencatat rata-rata kenaikan upah minimum tertinggi sebesar $25 \%$ Kalimantan Barat juga mencatat kenaikan pengangguran sebesar $10,66 \%$. Selanjutnya tren pertumbuhan ekonomi yang cend erung menurun berbanding terbalik dengan tren pengangguran di Kalimantan barat yang cenderung naik dan Kenaikan rata-rata upah minimum di Kalimanatan Barat berbanding lurus dengan tren pengangguran. Untuk menguji fenomena ini lebih jauh maka analisis selanjutnya digunakan uji regresi data panel

Tabel 3. Upah Minimum Kabupaten/Kota Kalimantan Barat (juta rupiah)

\begin{tabular}{llllll}
\hline Kabupaten/Kota & 2011 & 2012 & 2013 & 2014 & 2015 \\
\hline Kab. Sambas & 945.000 & 945.000 & 1.122 .500 & 1.450 .000 & 1.650 .000 \\
\hline Kab. Bengkayang & 975.500 & 975.500 & 1.255 .000 & 1.400 .000 & 1.560 .000 \\
\hline Kab. Landak & 851.000 & 940.000 & 1.125 .000 & 1.450 .000 & 1.606 .800 \\
\hline Kab. Mempawah & 910.000 & 910.000 & 1.143 .000 & 1.387 .000 & 1.575 .000 \\
\hline Kab. Sanggau & 854.000 & 925.000 & 1.118 .000 & 1.449 .000 & 1.765 .000 \\
\hline Kab. Ketapang & 886.000 & 1.050 .000 & 1.500 .000 & 1.650 .000 & 1.800 .000 \\
\hline Kab. Sintang & 857.000 & 950.000 & 1.126 .000 & 1450000 & 1.600 .000 \\
\hline Kab. Kapuas Hulu & 986.500 & 986.500 & 1.260 .000 & 1475000 & 1.600 .000 \\
\hline Kab. Sekadau & 855.000 & 910.000 & 1.180 .000 & 1450000 & 1.600 .000 \\
\hline Kab. Melawi & 960.000 & 960.000 & 1.180 .000 & 1470000 & 1.607 .000 \\
\hline Kab. Kayong Utara & 886.000 & 1.050 .000 & 1.390 .000 & 1600000 & 1.765 .000 \\
\hline Kab. Kubu Raya & 843.000 & 945.000 & 1.166 .000 & 1390000 & 1.580 .000 \\
\hline Kota Pontianak & 895.000 & 995.000 & 1.165 .000 & 1425000 & 1.600 .000 \\
\hline Kota Singkawang & 850.000 & 925.000 & 1.135 .000 & 1450000 & 1.650 .000 \\
\hline Sumber: Badan Pusat Statistik Kalimantan Barat & & &
\end{tabular}

Sumber: Badan Pusat Statistik Kalimantan Barat

\section{Analsisi Regresi Data Panel}

Setelah mengguanakn Uji Chow dan Uji Housman maka dapat diputuskan bahwa model yang digunakan adalah Fixed Effects Model dan dari pengolahan E-views 9 diperoleh hasil sebagai berikut:

\section{Model Fixed Effect}

$$
Y=-1,905246-0,118987 X_{1}+0,271169 X_{2}+e
$$

Tabel 7. Regresi Fixed Effects Model

\begin{tabular}{|c|l|}
\hline R-Squared & 0,890108 \\
\hline Adjusted R-Square & 0,859583 \\
\hline \multicolumn{2}{|c|}{ Sumber: Hasil pengolahan dengan E-views }
\end{tabular}

Berdasarkan hasil regresi di atas, nilai koefisien determinasi yang ditunjukkan dengan R-Square sebesar 0,890108. Artinya, variabel dependen mampu menjelaskan variabel independen sebesar 89\%, sedangkan sisanya sebesar $11 \%$ dijelaskan oleh variabel lain di luar model ini.

\section{Uji t}

Pertumbuhan Ekonomi (X1) memiliki nilai koefisien sebesar -0118987 dan nilai probabilitas sebesar 0.0000 . Hal ini menunjukkan bahwa nilai probabilitas kurang dari $\alpha=0,05$, sehingga dapat dikatakan bahwa 
variabel Pertumbuhan Ekonomi $(X 1)$ secara spasial berpengaruh secara negatif dan signifikan terhadap Tingkat Pengangguran Terbuka. Upah Minimum (X2) memiliki nilai koefisien sebesar 0,271169 dan nilai probabilitas sebesar 0,0063 . Hal ini menunjukkan nilai pribabilitas kurang dari $\alpha=0,05$, sehingga dapat disimpulkan bahwa variabel Upah Minimum (X2) secara spasial berpengaruh positif dan signifikan terhadap Tingkat Pengangguran Terbuka.

\section{Uji F}

Pertumbuhan Ekonomi (X1) dn Upah Minimum (X2) memiliki nilai probabilitas F-Statistic sebesar 0,000000. Hal ini menunjukkan nilai probabilitas pada penelitian ini kurang dari $\alpha=0,05$, sehingga dapat dikatakan bahwa variabel Pertumbuhan Ekonomi (X1) dan Upah Minimum (X2) berpengaruh signifikan secara bersama-sama terhadap Tingkat Pengangguran Terbuka.

\section{Koefisien Determinasi $\left(R^{2}\right)$}

Nilai koefisien determinannya berada diangka 0,890108. Hal ini berarti bahwa 89 perssen Tingkat Pengangguran Terbuka di Provinsi Kalimantan Barat dapat dijelaskan oleh variabel Pertumbuhan Ekonomi (PE) dan Upah Minimum (UMK). Sedangkan sisanya, yaitu 11 persen dijelaskan oleh variabel lain di luar model atau faktor-faktor di luar penelitian ini.

Hasil analisis yang telah dilakukan menunjukkan bahwa petumbuhan ekonomi berdampak negatif signifikan terhadap pengurangan pengangguran. Hal ini mengindikasikan semakin tinggi pertumbuhan ekonomi maka akan berdampak positif pada pengurangan pengangguran. Berdasarkan model, dengan asumsi setiap tahunnya upah minimum meningkat $10 \%$ untuk menjaga pengangguran tidak bertambah maka pertumbuhan ekonomi harus berada di angka 6,8\%. Namun, semisal Kalimantan Barat dapat menekan kenaikan upah minimum di angka $9 \%$ dan mampu menjaga stabilitas pertumbuhan ekonomi di angka 5\% maka penganggurang akan berkurang sebesar 6\%. Namun. dengan asumsi upah minimum di angka $9 \%$ setidaknya petumuhan ekonomi harus $4,5 \%$ agar pengangguran tidak bertambah. Sementara itu jika diasumsikan tidak ada kenaikan upah minimum maka dengan pertumbuhan ekonomi sebesar 5\% pengangguran akan berkurang sebesar $2,5 \%$.

Melalui model regresi yang didapatkan juga terlihat bahwa kenaikan upah minimum sangat berpengaruh terhadap jumlah pengangguran di Kalimantan Barat. Oleh karena itu, peran pengambil kebijakan dalam mengendalikan inflasi sangatlah diperlukan. Inflasi yang rendah akan berimplikasi pada terjangkaunya kebutuhan pokok sehingga akan membantu menjaga kenaikan upah minimum yang tidak terlalu tinggi. Data inflasi Badan Pusat Statistik Kalimantan Barat pada tahun 2015 menunjukkan angka $6,17 \%$ dengan inflasi tertinggi ada pada bahan makanan mencapai 9,98\% (BPS, 2018). Tingkat inflasi yang cukup tinggi di Kalimanatan Barat khususnya pada bahan makanan dikarenakan mayoritas kebutuhan pokok di Kalimanatan Barat berasal dari derah lain khususnya Jawa. Situasi tersebut membuat Kalimantan Barat sangat rentan terhadap kenaikan bahan bakar dan kondisi iklim (Kredit Gogo, n.d.).

Sementara itu untuk lebih mengoptimalkan peran pertumbuhan ekonomi dalam mengurangi pengangguran maka Kalimanatan Barat harus melakukan diversifikasi ekonomi. Mengarahkan pertumbuhan ekonomi yang lebih inklusif dan tidak sentralistik pada sektor pertanian dan pertambangan. Pertambangan di Kalimantan Barat masih menjadi salah satu sektor dengan proporsi terbesar dalam pertumbuhan ekonomi. Namun besarnya besaranya pertumbuhan ekonomi di sektor pertambangan tidak sebanding dengan besarnya penyerapan tenaga kerja. Oleh karena itu, diversifikasi ke non industri ekstraktif adalah keharusan. Beberapa data dari negara maju memperlihatkan jika pendorong utama pertumbuhan ekonomi mereka bukanlah sektor ekstraktif melainkan jasa pengolahan.

\section{KESIMPULAN DAN SARAN}

Secara statistik terlihat bahwa upah minimum berpengaruh positif signifikan terhadap pengangguran di Kalimantan Barat dan pertumbuhan ekonomi berpengaruh negatif signifikan terhadap jumlah pengangguran. Oleh sebab itu Kalimantan Barat harus mampu menekan kenaikan upah minimum dan mampu meningkatkan pertumbuhan ekonominya. Salah satu cara untuk menekan kenaikan upah minimum adalah dengan mengendalikan laju inflasi terutama kebutuhan bahan pokok dan meningkatkan laju pertumbuhan ekonomi dengan cara melakukan diversifikasi sektor industri.

\section{REFERENSI}

Al-Habees, M. A., \& Rumman, M. A. (2012). The relationship between unemployment and economic 
growth in Jordan and some Arab countries. World Applied Sciences Journal. https://doi.org/10.5829/idosiwasj.2012.18.06.2735

Alvarado, R., Iñiguez, M., \& Ponce, P. (2017). Foreign direct investment and economic growth in Latin America. Economic Analysis and Policy. https://doi.org/10.1016/j.eap.2017.09.006

Azman-Saini, W. N. W., Baharumshah, A. Z., \& Law, S. H. (2010). Foreign direct investment, economic freedom and economic growth: International evidence. Economic Modelling. https://doi.org/10.1016/j.econmod.2010.04.001

BPS. (2018). Tingkat Pengangguran Terbuka Menurut Propinsi 1986-2018. Retrieved from https://www.bps.go.id/statictable/2014/09/15/981/tingkat-pengangguran-terbuka-tpt-menurutprovinsi-1986---2018.html

Cahuc, P., \& Michel, P. (1996). Minimum wage unemployment and growth. European Economic Review. https://doi.org/10.1016/0014-2921(95)00035-6

Chong-Uk Kim, G. L. (2018). Minimum Wage and Unemployment: An Empirical Study on OECD Countries. Journal of Reviews on Global Economics, 7. https://doi.org/https://doi.org/10.6000/1929-7092.2018.07.01

Christiano, L. J., Eichenbaum, M., \& Trabandt, M. (2013). Unemployment and Business Cycles. SSRN. https://doi.org/10.2139/ssrn.2363493

Dieckhoff, M. (2011). The effect of unemployment on subsequent job quality in europe: A comparative study of four countries. Acta Sociologica. https://doi.org/10.1177/0001699311412798

Iamsiraroj, S. (2016). The foreign direct investment-economic growth nexus. International Review of Economics and Finance. https://doi.org/10.1016/j.iref.2015.10.044

Kingdon, G., \& Knight, J. (2007). Unemployment in South Africa, 1995-2003: Causes, problems and policies. Journal of African Economies. https://doi.org/10.1093/jae/ejm016

Kredit Gogo. (n.d.). 3 Alasan Biaya Hidup di Luar Pulau Jawa Lebih Mahal. Retrieved from https://kreditgogo.com/artikel/Informasi-Umum/3-Alasan-Biaya-Hidup-di-Luar-Pulau-Jawa-LebihMahal.html

Mortensen, D. T., \& Pissarides, C. A. (1994). Job Creation and Job Destruction in the Theory of Unemployment. The Review of Economic Studies. https://doi.org/10.2307/2297896

Özgür Bayram Soylu, İsmail Çakmak, F. O. (2017). Economic growth and unemployment issue: Panel data analysis in Eastern European Countries. Journal of International Studies, 11(1). https://doi.org/10.14254/2071- 8330.2018/11-1/7

Rodrik, D. (2008). Understanding South Africa's economic puzzles. In Economics of Transition. https://doi.org/10.1111/j.1468-0351.2008.00343.x

Statistics SA. (2014). Employment, unemployment, skills and economic growth. Statistics South Africa. Wiemers, E. E. (2014). The Effect of Unemployment on Household Composition and Doubling Up. Demography. https://doi.org/10.1007/s13524-014-0347-0 
